\title{
The Effect of Voluntary IFRS Adoption on MD\&A Information
}

\author{
Kento Inoue* $\quad$ Yoshitaka Hirose ${ }^{\dagger}$
}

\begin{abstract}
In this study, we analyze the Japanese-textual management discussion and analysis (MD\&A)
\end{abstract}

information of Japanese firms that voluntarily adopted International Financial Reporting Standards

(IFRS). We conduct a difference-in-differences (DID) analysis of firms voluntarily adopting IFRS

and those that continue to use Japanese generally accepted accounting principles (J-GAAP). The

results show that the IFRS voluntary adopters reduce characters compared to firms that continue

to use J-GAAP. However, the readability of MD\&A information does not change around IFRS

adoption. Overall, our results suggest that the voluntary IFRS adoption lowers disclosure levels in

this information. The contribution of this research to the international accounting literature is in

analyzing a non-English language, which is different from previous research. In particular, the analysis of Japanese - technically, a very difficult language — is an important feature of this study.

\footnotetext{
"Kindai University (kinoue@bus.kindai.ac.jp)

$†$ Osaka City University
} 
Keywords: International Financial Reporting Standards (IFRS); management discussion and analysis (MD\&A) information; textual analysis 


\section{INTRODUCTION}

Many firms are currently using the International Financial Reporting Standards (IFRS), and mandatory IFRS adoption for listed firms in the European Union (EU) is a significant development in international accounting. ${ }^{1}$ Currently, IFRS is used in more than 100 countries around the world, and thus, many studies analyze the effects of IFRS adoption. For example, studies address accounting quality (Barth, Landsman, and Lang 2008; Ahmed, Neel, and Wang 2013; Christensen,

Lee, Walker, and Zeng 2015), comparability (Yip and Young 2012; Cascino and Gassen 2015), and capital markets (Daske 2006; Daske, Hail, Leuz, and Verdi 2008, 2013; Li 2010; Christensen, Hail, and Leuz 2013).

Prior studies tend to focus on quantitative information, such as financial numbers and stock prices. One notable exception to this stream is a study by Lang and Sitce-Lawrance (2015), who analyze textual information and IFRS adoption and find that mandatory IFRS adoption increases disclosure levels and comparability while reducing boilerplate. However, one limitation of their

${ }^{1}$ IFRS was renamed in 2001 from the International Accounting Standards (IAS). In this paper, "IFRS" also refers to "IAS". 
study is using only English-language annual reports, whereas in some IFRS countries (e.g., Japan),

English is not the native language. Determining the effect of IFRS adoption in other countries would require analysis in the native languages. Moreover, these researchers analyze the full text of annual reports, which have many kinds of qualitative information, including management discussion and analysis (MD\&A) information and note information. Applying a different approach from this study and analyzing only one kind of annual report information can yield more detailed results on the effects of IFRS adoption. Therefore, we choose to study the effect of IFRS adoption specifically on MD\&A information for Japanese firms that voluntarily adopted IFRS.

For this purpose, we choose to conduct a difference-in-differences (DID) analysis with propensity score matching (PSM). Previous studies suggest that the adoption of IFRS can have different effects depending on the characteristics of firms and countries (e.g., Christensen et al., 2013; Daske et al., 2013). In this study, we control the effect of institutional factors by using only Japanese firms. In addition, we perform PSM, matching IFRS adopters with similar firms that continue using Japanese generally accepted accounting principles (J-GAAP). This approach controls firms' characteristics. 
We use Japanese listed firms that voluntarily adopted IFRS in fiscal years ending on or after March 31, 2010, through March 31, 2017 and conduct a DID analysis of the IFRS adopters versus those continuing to use J-GAAP. The results show that the IFRS firms used fewer characters than firms that continue with J-GAAP. However, the Japanese language readability of the MD\&A information do not change with IFRS adoption. Overall, our results indicate that adoption lowers the disclosure levels in this information. The contribution of this research to international accounting is that in contrast to previous studies, it analyzes a non-English language. Particularly, it analyzes Japanese, which is technically a very difficult language.

The remainder of the paper proceeds as follows. We discuss prior literature in Section 2 and explain research design in Section 3. We present the basic empirical findings on readability in Section 4, and Section 5 concludes the paper.

\section{LITERATURE REVIEW}

\section{The Effects of IFRS Adoption}

There is a large body of literature on the effects of IFRS adoption. The purpose of mandatory

IFRS adoption in the EU is to improve transparency and comparability (EC Regulation No. 
1606/2002), and several previous studies address whether IFRS adoption achieved these aims. For example, studies address issues of (1) accounting quality, (2) comparability, and (3) capital markets.

Analyses of accounting quality include Barth et al. (2008), who explore voluntary IFRS adoption, and find that voluntary IFRS adoption improved accounting quality. In contrast, Ahmed et al. (2013) analyze mandatory IFRS adoption and show that mandatory adoption reduces the quality. In another strand of the literature, Yip and Young (2012) analyze the impact of mandatory IFRS adoption, and they find that mandatory IFRS adoption increased comparability. Cascino and Gassen (2015) also find evidence that mandatory IFRS adoption improves comparability, but their result is more limited.

In an analysis of capital markets, Daske et al. (2008) confirm that mandatory IFRS adoption increases market liquidity and decreases the cost of capital. Li (2010) also shows that mandatory IFRS adoption reduces the cost of capital. These results suggest that capital markets benefit from IFRS adoption. On the other hand, in Daske (2006), the voluntary IFRS adoption increases the cost of capital. The first reason for this mixed evidence has to do with reporting incentives. The effects of IFRS adoption is observed from an incentive to report on transparency, rather than IFRS 
adoption per se. Daske et al. (2013) discover that, among firms adopting IFRS, those who are committed to increasing financial reporting transparency exhibit increased market liquidity and reduced the cost of capital. Christensen et al. (2015) confirm that accounting quality improves in the firms with a commitment to financial transparency, that is, voluntary adopters.

The institutional environments of different countries may affect IFRS adoption. Even though IFRS is considered a high-quality accounting standard, countries with weak enforcement may not receive the positive effects of IFRS. Christensen et al. (2013) reveal that in countries increasing enforcement while adopting IFRS, market liquidity increases. In addition, the enforcement also influences the cost of capital (Daske et al. 2008; Li 2010) and comparability (Cascino and Gassen 2015). Overall, the results of previous studies suggest that the effects of IFRS adoption stem less from IFRS, itself, and more from the unique characteristics of the firms and countries.

\section{Textual Information Analysis}

Li (2008) conduct the first study on readability using large-scale archival data. This author examines the readability of annual reports using the number of words and the Fog index, which is based on the average number of words in a sentence and the percentage of words with three or 
more syllables. For example, a score of six would indicate a reading level appropriate for someone with six years of elementary education, while 17 would indicate a reading level appropriate for a university graduate. By analyzing the MD\&A sections of annual reports, this researcher finds that readability is related to firms' future performance. Specifically, the researcher finds that the information from less profitable firms has low readability (a high Fog index and many words) and vice versa: firms with more readable annual reports tend to be more profitable. This study is significant in that it pioneers the simultaneous exploration of annual report readability and corporate financial performance. After it is published in 2008, similar research papers is published in major academic journals almost every year.

In subsequent accounting studies, Lehavy, Li, and Merkley (2011), Lee (2012), Lawrence (2013), and Lundholm, Rogo, and Zhang (2014) analyze financial archival data together with textual information. Meanwhile, Biddle, Hilary, and Verdi (2009) examine the efficiency of capital investments by combining two accrual indices and a readability index (Fog index) into a variable and using it to represent the quality of financial reporting (FRQ Index). This is similar to Li (2008) using the Fog index as a readability index for annual reports. 
Furthermore, Miller (2010) analyzes the impact of financial reporting complexity on investor behavior and determines that more complex, longer, and less readable 10-K reports are associated with lower trading volumes. This relationship is more pronounced with lower retail investor activity. A study on the complexity of financial reporting emphasizes practical contributions to the US Securities and Exchange Commission (SEC), which is promoting plain English disclosures (SEC, 1998). Meanwhile, Lawrence (2013) focuses on retail investors and discovers that both the Fog index and the length of the annual report is related to individual investor shareholding. In this study, individual investors invest more in firms with shorter (in terms of number of words) and more readable annual reports. These results suggest that both the form and content of the disclosure influence individual investors' investment decisions. However, this finding is found to be less pronounced for retail investors who trade more than 48 times a year. This study provides yet another example of how accounting research often uses the Fog index to represent the readability of English text.

It should be mentioned that readability as an aspect of financial reporting quality is a somewhat novel concept. Moreover, in these settings, readability is not evaluated from a linguistic perspective. Rather, readability studies tend to rely on the Fog index, arguing for the validity of 
the approach base on its precedent in early research using archival or small sample data. However, some criticize the use or overuse of the Fog index. For example, Loughran and McDonald (2014) express concerns about the application of the Fog index to business documents, as the definition of a "difficult" word may depend on the context in which the word appears. In other words, a word with multiple syllables may not always be a difficult word. For example, these words with three syllables frequently appear in business documents: "company," "business," and "directors." According to the Fog index, the more these words appear in a document, the more difficult the document would be to read. However, most investors or creditors would be very familiar with these words. Thus, critics suggest using only the number of words in business documents as the simple surrogate measure of readability.

While the above-mentioned studies analyze English-language disclosure documents for US firms headquartered in the US, in recent years, researchers also study foreign firms with US headquarters. For example, Lundholm, et al. (2014) explore the readability and financial data of annual reports and press releases of foreign firms listed on the US Stock Exchange. They find that foreign firms are more explicit than US firms and refer more often to financial data. An even more 
important finding is that firms that are more geographically distant from the US have more readable reports.

Lang and Stice-Lawrence (2015) analyze textual information and the adoption of IFRS, comparing qualitative information from an international accounting perspective. They analyze more than 15,000 annual reports from 1998 to 2011; these reports were from 42 countries, not including the US. They find that the mandatory adoption of IFRS increases disclosure and comparability while reducing boilerplate. However, they analyze only English-language annual reports, and this is a limitation of their study. Furthermore, Lo, Ramos, and Rogo (2017) examine how the readability of annual reports changes with earnings management and find that firms do earnings management in the previous year have more difficulty with MD\&A.

As described above, most prior researches analyze textual information in the entire annual report, but a few studies exclusively focus on MD\&A. In this study, we adopt the latter approach (MD\&A) as the message from firms' management. When analyzing the entire annual report, it is more difficult to tease out this underlying message.

Thus, in this study, we analyze the effect of IFRS adoption on Japanese textual information, focusing on MD\&A. This is an approach that previous studies have not undertaken. In addition, 
we use PSM to control corporate characteristics that may play a role in the effects of IFRS adoption.

By analyzing only Japanese firms, institutional characteristics are also controlled.

\section{RESEARCH DESIGN}

\section{Variables}

To analyze the effects of IFRS adoption on MD\&A, we examine Length $_{i, t}$ and Readability $y_{i, t}$

(Hirose et al., 2017). Length $h_{i, t}$ is a variable indicating the number of characters in the MD\&A

information of the report for firm $i$ in year $t$, and we use a logarithmically transformed value

$\left(\ln \left(\right.\right.$ Length $\left.\left._{i, t}\right)\right)$. If the number of characters in the MD\&A information increases (decreases) with

IFRS adoption, we expect that $\ln ($ Length) will increase (decrease) significantly.

Second, Readability $i$, is defined as the texts' level of difficulty in terms of school grade level

for firm $i$ in year $t$ (Shibasaki and Tamaoka 2010). A text with a score of one, for example, would

have a difficulty level appropriate for someone in the first grade of elementary school, while a text

with a score of nine would exhibit a difficulty level appropriate for someone in grade nine, and so

on. The model is shown in equation (1). 


$$
Y=-0.145 X_{1}+0.587 X_{2}+14.016
$$

Japanese text is composed of kanji, hiragana, katakana, and romaji. The more often a text uses

hiragana, the less difficult it is to read. $X_{1}$ indicates the amount of hiragana in the text. Analyzing 243 textbooks, Shibasaki and Tamaoka (2010) show that as the grade level of the text increases, the amount of hiragana decreases while kanji increases. $X_{2}$ represents the number of predicates in the text. When many predicates exist in one sentence, the sentence is more difficult. This also follows Shibasaki and Tamaoka (2010), who show that the number of predicates increases as the grade level increases. $Y$ as estimated by equation (1) indicates the grade level. If the difficulty of a text is increasing (decreasing) with IFRS adoption, we expect that Readability will increase (decrease) significantly.

\section{Sample Selection}

\section{IFRS Adopter Sample}

Table 1 shows our sample selection procedures. In fiscal years ending on or after March 31, 2010, through March 31, 2017, there are 121 Japanese listed firms who voluntarily adopted IFRS. 
First, we exclude 10 firms that adopted IFRS during their initial public offering (IPO). Then, we exclude four firms from the financial industry according to the Tokyo Stock Exchange's industrial classification (7050, 7100, 7150, and 7200), and we also exclude 12 firms that adopted US-GAAP before IFRS. Finally, we exclude two firms within the analysis period that has fiscal years that are not 12 months. Our final sample is 93 firms. We obtain financial data on these firms from NEEDSFinancialQUEST database and obtain MD\&A information from EDINET database and eol database.

$<$ Table 1 inserts here $>$

Table 2 shows the distribution of our sample, indicating that the number of Japanese firms adopting IFRS increased after 2013 (the fiscal year ending April 30, 2013 through March 31, 2014). ${ }^{2}$ Within the Electric Appliances (12 firms), Pharmaceutical (11 firms), Transport Equipment (11 firms), Information \& Communication (11 firms), and Service (10 firms) industries, we find that many firms adopted IFRS. Moreover, within industries, firms tend to adopt IFRS in

2 Table 2 follows the Japanese calendar. In Japan, the year begins in April and ends in March. For example, 2016 indicates the number of IFRS adopting firms at the fiscal year ending April 30, 2016 through March 31, 2017. 
same period (e.g., Pharmaceutical in 2013, Electric Appliances and Transport Equipment in 2014).

This may be because firms in the same industry are using the same accounting standards.

$<$ Table 2 inserts here $>$

\section{Propensity Score Matching}

For this study, we employ the DID analysis method, which allows us to compare the IFRS adopters with the J-GAAP firms as the benchmark sample. We use PSM to select the benchmark sample. Following previous studies that analyze the determinants of Japanese firms' IFRS adoption (Inoue and Ishikawa 2014; Sato and Takeda 2017; Kameoka. Okumura, and Yan 2019;

Kim, Nakano, Naruoka 2019), we use equation (2) to estimate the propensity score.

$$
\begin{aligned}
& \operatorname{Prob}(I F R S=1 \mid x)=F\left(\beta_{0}+\beta_{1} G O O D W I L L_{i, t}+\beta_{2} R \& D_{i, t}+\beta_{3} F_{-} S A L E S_{i, t}\right. \\
& +\beta_{4} F_{-} S H A R E_{i, t}+\beta_{5} S_{I Z E_{i, t}}+\beta_{6} L_{E V E R A G E} E_{i, t} \\
& \left.+\beta_{7} R O A_{i, t}+\beta_{8} A G E_{i, t}+\text { YearDummies }+ \text { IndustryDummies }\right)
\end{aligned}
$$

where

$I F R S_{i}=$ A dummy variable that takes the value of 1 if firm $i$ voluntarily adopted IFRS and 0

otherwise, 
GOODWIL $L_{i, t}=$ goodwill for firm $i$ in year $t$, divided by total assets,

$R \& D_{i, t}=$ research and development expenses for firm $i$ in year $t$, divided by sales,

$F \_S A L E S_{i, t}=$ sales in foreign countries for firm $i$ in year $t$, divided by sales,

$F_{-} S H A R E_{i, t}=$ foreigner ownership ratio for firm $i$ in year $t$ [foreigner ownership number /

(number of outstanding shares - number of treasury shares)],

$S I Z E_{i, t}=$ natural logarithm of total assets for firm $i$ in year $t$,

$L E V E R A G E_{i, t}=$ total debt for firm $i$ in year $t$, divided by total assets,

$R O A_{i, t}=$ return on assets for firm $i$ in year $t$ [net income / total assets],

$A G E_{i, t}=$ natural $\log$ of the number of years elapsed from the establishment year to the current

year for firm $i$ in year $t$,

YearDummies $=$ year dummies variables,

IndustryDummies $=$ industrial dummies variables. ${ }^{3}$

${ }^{3}$ All continuous variables are winsorized at their1st and 99th percentiles. 
We run the logit regression of equation (2) using IFRS adopters' financial data from the year previous to the IFRS adoption and the J-GAAP firms' data from fiscal years ending on or after September 30, 2008, through September 30, 2016. Using the estimated propensity score from equation (2), we match the IFRS adopter in the year prior to IFRS adoption with the J-GAAP firm in the six months before and after the IFRS adopter's fiscal year end. This matching method is the one-to-one Nearest Neighbor method without replacement. As a result, we obtain a benchmark sample of 82 firms (93 observations).

Panel A in Table 3 shows the result of the logit regression from equation (2). We find that GOODWILL, F_SALES, F_SHARE, and SIZE are significantly positive, and $A G E$ is significantly negative. This indicates that IFRS adopters have more goodwill, higher sales in foreign countries, and more foreign stockholders. They are also larger and newer than J-GAAP firms.

$<$ Table 3 insert here $>$

Panel B in Table 3 shows the results of tests on the mean of the variables used in equation (2) before and after matching. This allows us to see the balance between IFRS adopters and J-GAAP firms. Before matching, there are significant differences in variables between IFRS adopters and J-GAAP firms except for $L E V E R A G E$ and $A G E$. On the other hand, after matching, the differences 
in the variables are not significant. We interpret this as indicating that our matching eliminates the characteristic differences between IFRS adopters and J-GAAP firms.

\section{RESULTS}

Table 4 shows our descriptive statistics. The IFRS adopter's average and median Length decreases from the period before adoption (Panel A) to the period after adoption (Panel B). This indicates that the number of characters in the text decrease with the adoption of IFRS. On the other hand, Readability increases with IFRS adoption. This shows that the content of the MD\&A text became more difficult with IFRS adoption.

$<$ Table 4 insert here $>$

Table 5 shows the results of the DID analysis. The lower right side of Panel A shows that $\ln ($ Length $)$ is significantly negative at the $1 \%$ level. This result indicates that compared to J-GAAP firms, IFRS adopters reduce characters in their MD\&A information around IFRS adoption. Panel B shows the result for Readability, and it is not significant. During the IFRS adoption period, the adopters' text readabilities did not change.

$<$ Table 5 insert here $>$ 
Overall, our result shows that voluntary IFRS adoption reduce the number of characters in MD\&A information. This result suggests that IFRS adoption by Japanese firms lowers disclosure levels in the MD\&A information.

\section{CONCLUSION}

In this study, we analyze changes in Japanese language MD\&A information after Japanese firms voluntarily adopted IFRS. We perform a DID analysis of firms voluntarily adopting IFRS compared to those continuing to use J-GAAP. The results show that firms that adopted IFRS reduce characters compared to those that continue with J-GAAP. However, the Japanese readability of the MD\&A information did not change after firms adopted IFRS. Overall, our result suggests that the IFRS adoptions lower disclosure levels in this information. This study's contribution to the international accounting literature is in providing an analysis in a non-English language. The fact that we have analyze Japanese — a technically very difficult language — is another important feature of this study. Future international accounting studies should continue to analyze languages other than English.

\section{REFERENCES}


Ahmed, A. S., M. Neel, and D. Wang. 2013. Does mandatory adoption of IFRS improve accounting quality? Preliminary evidence. Contemporary Accounting Research 30 (4): 1344-1372.

Barth, M. E., W. R. Landsman, and M. H. Lang. 2008. International Accounting Standards and accounting quality. Journal of Accounting Research 46 (3): 467-498.

Biddle, G. C., G. Hilary, and R. S. Verdi. 2009. How does financial reporting quality relate to investment efficiency? Journal of Accounting and Economics 48 (2): 112-131.

Cascino, S., and J. Gassen. 2015. What drives the comparability effect of mandatory IFRS adoption? Review of Accounting Studies 20 (1): 242-282.

Christensen, H. B., L. Hail, and C. Leuz. 2013. Mandatory IFRS reporting and changes in enforcement. Journal of Accounting and Economics 56 (2-3): 147-177.

Christensen, H. B., E. Lee, M. Walker, and C. Zeng. 2015. Incentives or standards: What determines accounting quality changes around IFRS adoption? European Accounting Review 24 (1): 31-61. 
Daske, H. 2006. Economic benefits of adopting IFRS or US-GAAP - Have the expected cost of equity capital really decreased? Journal of Business Finance and Accounting 33 (3-4): 329-373.

Daske, H., L. Hail, C. Leuz, and R. Verdi. 2008. Mandatory IFRS reporting around the world: Early evidence on the economic consequences. Journal of Accounting Research 46 (5): $1085-1142$.

Daske, H., L. Hail, C. Leuz, and R. Verdi. 2013. Adopting a label: Heterogeneity in the economic consequences around IAS/IFRS adoptions. Journal of Accounting Research 51 (3): 495547.

Hirose Y., H. Hirai, and K. Arai. 2017. Effects of Readability of MD\&A Information on Future Performance: The Analysis of Text Mining. The Journal of Business Analysis (33), 87101. (In Japanese)

Inoue, K., and H. Ishikawa. 2014 The effect of IFRS on capital markets. Securities Analyst Journal 52 (9): 28-40. (In Japanese)

Kameoka, E., M. Okumura, and S. Yan. 2019. Firms’ voluntary IFRS adoption and network effects. Available at SSRN: https://ssrn.com/abstract $=3238517$. 
Kim, J., T. Nakano, and H. Naruoka. 2019. Characteristics of companies that voluntarily adopted the IFRS. Accounting Progress (20): 78-94. (In Japanese)

Lang, M., and L. Stice-Lawrence. 2015. Textual analysis and international financial reporting: Large sample evidence. Journal of Accounting and Economics 60 (2): 110-135.

Lawrence, A. 2013. Individual investors and financial disclosure. Journal of Accounting and Economics, 56 (1): 130-147.

Lee, Y. J. 2012. The effect of quarterly report readability on information efficiency of stock prices. Contemporary Accounting Research 29 (4): 1137-1170.

Lehavy, R., F. Li, and K. Merkley. 2011. The effect of annual report readability on analyst following and the properties of their earnings forecasts. The Accounting Review 86 (3): $1087-1115$.

Li, F. 2008. Annual report readability, current earnings, and earnings persistence. Journal of Accounting and Economics 45 (2): 221-247. 
Li, S. 2010. Does Mandatory Adoption of international financial reporting standards in the European Union reduce the cost of equity capital? The Accounting Review 85 (2): $607-$ 636.

Lo, K., F. Ramos, and R. Rogo. 2017. Earnings management and annual report readability. Journal of Accounting and Economic 63 (1): 1-25.

Loughran, T., and B. McDonald. 2014. Measuring readability in financial disclosures. The Journal of Finance 69 (4): 1643-1671.

Lundholm, R. J., R. Rogo, and J. L. Zhang. 2014. Restoring the tower of Babel: How foreign firms communicate with US investors. The Accounting Review 89 (4): 1453-1485.

Miller, B. P. 2010. The effects of reporting complexity on small and large investor trading. The Accounting Review 85 (6): 2107-2143.

Sato, S., and F. Takeda. 2017. IFRS adoption and stock prices of Japanese firms in governance system transition. The International Journal of Accounting 52 (4): 319-337. 
Securities and Exchange Commission (SEC). 1998. A plain English handbook: How to create clear SEC disclosure. SEC Office of Investor Education and Assistance. Available at: http://www.sec.gov/pdf/handbook.pdf.

Shibasaki, H. and K. Tamaoka. 2010. Constructing a formula to predict school grades 1-9 based on Japanese language school textbooks. Japan Journal of Educational Technology 33 (4): 449-458. (In Japanese)

Yip, R. W. Y., and D. Young. 2012. Does mandatory IFRS adoption improve information comparability? The Accounting Review 87 (5): 1767-1789. 


\section{TABLE 1: Sample Selection}

Voluntary IFRS adoption of Japanese listing firm from 2010 to 2017

Delete: Firms that adopted IFRS during their IPO

Delete: Financial firms (Tokyo Stock Exchange's Industrial Classification 7050, 7100, 7150, 7200)

Delete: US-GAAP adoption firms before adopting IFRS

Delete: Firms within the analysis period that has fiscal years that are not 12 months

Final Sample

We obtain financial data from NEEDS-FinancialQUEST database and obtain MD\&A information from EDINET database and eol database. 
TABLE 2:Sample Distribution

\begin{tabular}{|c|c|c|c|c|c|c|c|c|c|}
\hline & 2009 & 2010 & 2011 & 2012 & 2013 & 2014 & 2015 & 2016 & Total \\
\hline Foods (3050) & 0 & 0 & 1 & 0 & 0 & 0 & 0 & 2 & 3 \\
\hline Chemicals (3200) & 0 & 0 & 0 & 0 & 0 & 2 & 0 & 4 & 6 \\
\hline Pharmaceutical (3250) & 0 & 0 & 0 & 0 & 6 & 2 & 1 & 2 & 11 \\
\hline Oil \& Coal Products (3300) & 0 & 0 & 0 & 0 & 0 & 0 & 0 & 1 & 1 \\
\hline Rubber Products (3350) & 0 & 0 & 0 & 0 & 0 & 0 & 1 & 1 & 2 \\
\hline Glass \& Ceramics Products (3400) & 0 & 0 & 1 & 0 & 1 & 0 & 0 & 0 & 2 \\
\hline Iron \& Steel (3450) & 0 & 0 & 0 & 0 & 0 & 1 & 0 & 0 & 1 \\
\hline Nonferrous Metals (3500) & 0 & 0 & 0 & 0 & 0 & 0 & 0 & 1 & 1 \\
\hline Metal Products (3550) & 0 & 0 & 0 & 0 & 0 & 0 & 2 & 0 & 2 \\
\hline Machinery (3600) & 0 & 0 & 0 & 0 & 0 & 2 & 1 & 0 & 3 \\
\hline Electric Appliances (3650) & 1 & 0 & 0 & 1 & 0 & 5 & 1 & 4 & 12 \\
\hline Transport Equipment (3700) & 0 & 0 & 0 & 0 & 0 & 6 & 3 & 2 & 11 \\
\hline Precision Instruments (3750) & 0 & 1 & 0 & 0 & 0 & 0 & 1 & 1 & 3 \\
\hline Other Products (3800) & 0 & 0 & 0 & 0 & 0 & 0 & 0 & 1 & 1 \\
\hline Land Transportation (5050) & 0 & 0 & 0 & 0 & 0 & 1 & 0 & 1 & 2 \\
\hline Information \& Communication (5250) & 0 & 0 & 0 & 0 & 2 & 2 & 3 & 4 & 11 \\
\hline Wholesale Trade (6050) & 0 & 0 & 0 & 1 & 1 & 1 & 1 & 1 & 5 \\
\hline Retail Trade (6100) & 0 & 0 & 0 & 0 & 0 & 2 & 0 & 2 & 4 \\
\hline Real Estate (8050) & 0 & 0 & 0 & 0 & 1 & 0 & 1 & 0 & 2 \\
\hline Services $(9050)$ & 0 & 0 & 0 & 1 & 1 & 2 & 1 & 5 & 10 \\
\hline Total & 1 & 1 & 2 & 3 & 12 & 26 & 16 & 32 & 93 \\
\hline
\end{tabular}

This industry classification is classified by the Tokyo Stock Exchange. The year follows the Japanese calendar. In Japan, the year begins in April and ends in March. For example, 2016 indicates the number of IFRS adopting firms at the fiscal year ending April 30, 2016 through March 31, 2017. 
TABLE 3: Propensity Score Matching

Panel A: Logit Model for Estimating Propensity Score

\begin{tabular}{|c|c|c|}
\hline & coefficient & $z$-statistic \\
\hline Constant & -31.364 & -0.011 \\
\hline GOODWILL & 19.126 & $8.269 * * *$ \\
\hline$R \& D$ & 4.794 & 1.018 \\
\hline F_SALES & 1.220 & $1.956^{*}$ \\
\hline F_SHARE & 2.033 & $1.942 *$ \\
\hline SIZE & 0.742 & $7.993 * * *$ \\
\hline LEVERAGE & 0.296 & 0.389 \\
\hline$R O A$ & 0.069 & 0.027 \\
\hline$A G E$ & -0.407 & $-2.708^{* *}$ \\
\hline YearDummies & YES & \\
\hline IndustryDummies & YES & \\
\hline Pseudo $R^{2}$ & 0.377 & \\
\hline$N$ & 25,303 & \\
\hline
\end{tabular}

Panel B: Balance Check

\begin{tabular}{|c|c|c|c|c|c|c|}
\hline & \multicolumn{3}{|c|}{ Before Matching } & \multicolumn{3}{|c|}{ After Matching } \\
\hline & IFRS & J-GAAP & $t$-statistic & IFRS & J-GAAP & $t$-statistic \\
\hline GOODWILL & 0.048 & 0.007 & $6.725 * * *$ & 0.048 & 0.044 & 0.583 \\
\hline$R \& D$ & 0.038 & 0.014 & $4.348 * * *$ & 0.038 & 0.034 & 0.564 \\
\hline F_SALES & 0.346 & 0.116 & $7.354 * * *$ & 0.346 & 0.343 & 0.067 \\
\hline$F \_S H A R E$ & 0.256 & 0.081 & $12.673 * * *$ & 0.256 & 0.263 & -0.352 \\
\hline SIZE & 12.563 & 10.237 & $12.176 * * *$ & 12.563 & 12.194 & 1.505 \\
\hline LEVERAGE & 0.479 & 0.486 & -0.358 & 0.479 & 0.445 & 1.307 \\
\hline$R O A$ & 0.037 & 0.018 & $3.088 * * *$ & 0.037 & 0.042 & -0.748 \\
\hline$A G E$ & 3.703 & 3.744 & -0.469 & 3.703 & 3.692 & 0.074 \\
\hline
\end{tabular}

$I F R S_{i}=$ A dummy variable that takes the value of 1 if firm $i$ voluntarily adopted IFRS and 0 otherwise; GOODWILL $=$ goodwill for firm $i$ in year $t$, divided by total assets; $R \& D_{i, t}=$ research and development expenses for firm $i$ in year $t$, divided by sales; $F \_S A L E S_{i, t}=$ sales in foreign countries for firm $i$ in year $t$, divided by sales; $F \_S H A R E_{i, t}=$ foreigner ownership ratio for firm $i$ in year $t$ [foreigner ownership number / (number of outstanding shares - number of treasury shares)]; SIZE $E_{i, t}=$ natural logarithm of total assets for firm $i$ in year $t ; L E V E R A G E_{i, t}=$ total debt for firm $i$ in year $t$, divided by total assets; $R O A_{i, t}=$ return on assets for firm $i$ in year $t$, [net income / total assets]; $A G E_{i, t}=$ natural log of the number of years elapsed from the establishment year to the current year for firm $i$ in year $t$; YearDummies $=$ year dummies variables, IndustryDummies = industrial dummies variables. All continuous variables are winsorized at their 1st and 99th percentiles. *, $* *$, and $* * *$ indicate statistical significance at $0.10,0.05$, and 0.01 level, respectively. 
TABLE 4: Descriptive Statistics

Panel A: IFRS Adopters in Pre-Adoption Year

\begin{tabular}{|c|c|c|c|c|c|c|c|}
\hline & Mean & Std. Dev. & Min & 25 th & Median & 75 th & Max \\
\hline Length & 3,342 & 2,883 & 351 & 1,799 & 2,876 & 4,110 & 24,756 \\
\hline $\ln ($ Length $)$ & 7.879 & 0.624 & 6.282 & 7.495 & 7.964 & 8.321 & 9.028 \\
\hline Readability & 11.247 & 0.538 & 10.166 & 10.869 & 11.231 & 11.541 & 12.688 \\
\hline
\end{tabular}

Panel B: IFRS Adopters in Adoption Year

\begin{tabular}{|c|c|c|c|c|c|c|c|}
\hline & Mean & Std. Dev. & Min & 25 th & Median & 75 th & Max \\
\hline Length & 2,595 & 2,409 & 367 & 1,286 & 2,186 & 2,958 & 21,251 \\
\hline $\ln ($ Length $)$ & 7.621 & 0.631 & 6.282 & 7.159 & 7.689 & 7.992 & 9.028 \\
\hline Readability & 11.275 & 0.547 & 10.325 & 10.821 & 11.251 & 11.566 & 12.688 \\
\hline
\end{tabular}

Panel C: J-GAAP Adopters in Pre-Adoption Year

\begin{tabular}{|c|c|c|c|c|c|c|c|}
\hline & Mean & Std. Dev. & Min & 25th & Median & 75 th & Max \\
\hline Length & 2,323 & 1,367 & 549 & 1,429 & 1,999 & 2,900 & 8,044 \\
\hline $\ln ($ Length $)$ & 7.594 & 0.569 & 6.308 & 7.264 & 7.600 & 7.972 & 8.992 \\
\hline Readability & 11.299 & 0.498 & 10.166 & 10.955 & 11.272 & 11.615 & 12.688 \\
\hline
\end{tabular}

Panel D: J-GAAP Adopters in Adoption Year

\begin{tabular}{|c|c|c|c|c|c|c|c|}
\hline & Mean & Std. Dev. & Min & 25th & Median & 75th & Max \\
\hline Length & 2,227 & 1,263 & 503 & 1,482 & 1,974 & 2773 & 6,972 \\
\hline $\ln ($ Length $)$ & 7.564 & 0.546 & 6.282 & 7.301 & 7.587 & 7.927 & 8.849 \\
\hline Readability & 11.322 & 0.516 & 10.166 & 11.006 & 11.304 & 11.655 & 12.688 \\
\hline
\end{tabular}

Length $_{i, t}=$ the number of characters in the MD\&A information of the report for firm $i$ in year $t ; \ln (\text { Length })_{i, t}=$ natural logarithm of Length $_{i, t}$; Readability ${ }_{i, t}=$ the texts' level of difficulty in terms of school grade level for firm $i$ in year $t$ (Shibasaki and Tamaoka, 2010), which is estimated from equation (1). $\ln \left(\right.$ Length $_{i, t}$ and Readability Rit, $_{\text {are }}$ winsorized at their $1 \mathrm{st}$ and 99th percentiles. 


\section{TABLE 5: Difference-in-Differences Analysis}

Panel A: $\ln ($ Length $)$

\begin{tabular}{|c|c|c|c|c|}
\hline \multirow{4}{*}{$\begin{array}{l}\text { Pre-Adoption Year } \\
\text { Adoption Year }\end{array}$} & & $\begin{array}{l}\text { IFRS Adopter } \\
\text { (a) }\end{array}$ & $\begin{array}{l}\text { J-GAAP Adopter } \\
\text { (b) }\end{array}$ & \multirow{4}{*}{$\begin{array}{l}(\mathrm{a})-(\mathrm{b}) \\
0.284 * * * \\
0.056 \\
-0.227 * * *\end{array}$} \\
\hline & (I) & 7.879 & 7.594 & \\
\hline & (II) & 7.621 & 7.564 & \\
\hline & (II) - (I) & \multicolumn{2}{|l|}{$-0.258 * * *$} & \\
\hline \multicolumn{5}{|c|}{ Panel B: Readability } \\
\hline \multirow{4}{*}{$\begin{array}{l}\text { Pre-Adoption Year } \\
\text { Adoption Year }\end{array}$} & & $\begin{array}{l}\text { IFRS Adopter } \\
\text { (a) }\end{array}$ & $\begin{array}{c}\text { J-GAAP Adopter } \\
\text { (b) }\end{array}$ & \multirow{4}{*}{$\begin{array}{c}(a)-(b) \\
-0.052 \\
-0.046 \\
0.006\end{array}$} \\
\hline & (I) & 11.247 & 11.299 & \\
\hline & (II) & 11.275 & 11.322 & \\
\hline & $(\mathrm{II})-(\mathrm{I})$ & 0.028 & 0.022 & \\
\hline
\end{tabular}

$\ln (\text { Length })_{i, t}=$ natural logarithm of the number of characters in the MD\&A information of the report for firm $i$ in year $t$; Readability $_{i, t}=$ the texts' level of difficulty in terms of school grade level for firm $i$ in year $t$ (Shibasaki and Tamaoka, 2010), which is estimated from equation (1). All continuous variables are winsorized at their 1 st and 99th percentiles. *, **, and $* * *$ indicate statistical significance at $0.10,0.05$, and 0.01 level, respectively. 